\title{
動物賽驗に於て攝取する飼料の量が及ぼす影響に就いて
}

中村䔀三

（イリノイ大學農學部然釒研究室 $)^{(1}$

昭利 16 年 3 月 25 日艰理

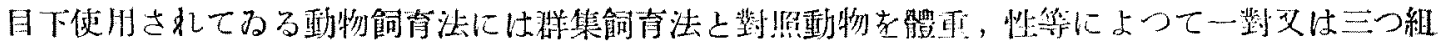

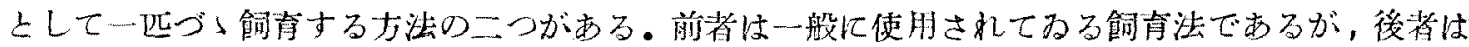

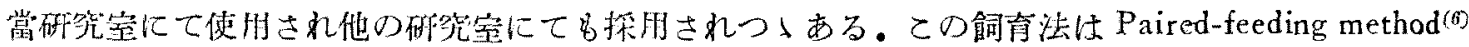

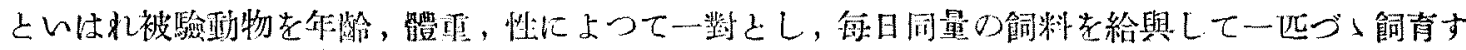

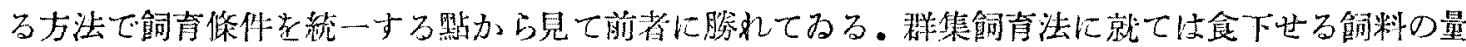

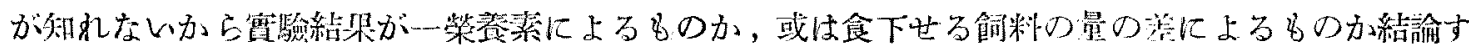
ることの出來ないタのが橴山ある。

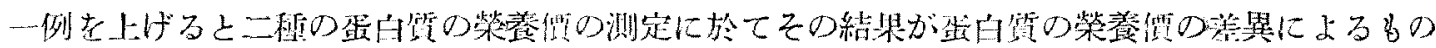

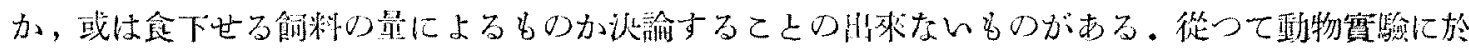

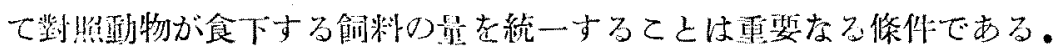

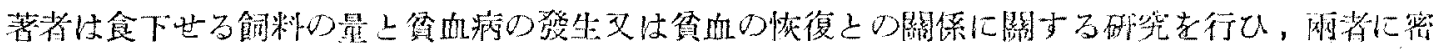

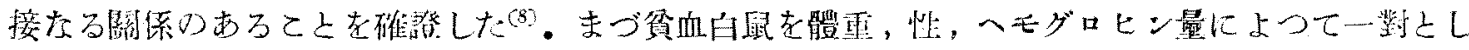

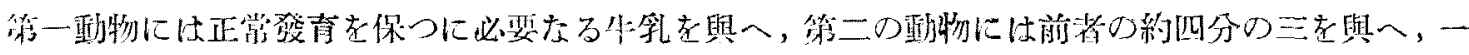

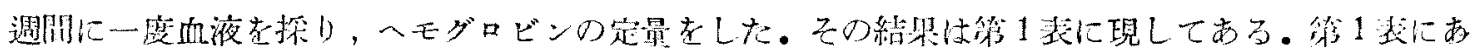

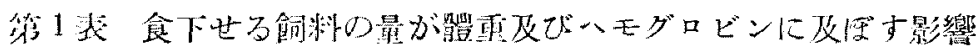

\begin{tabular}{|c|c|c|c|c|c|c|c|c|c|c|c|}
\hline \multirow{2}{*}{\multicolumn{2}{|c|}{ 白鼠番號, 性 }} & \multicolumn{2}{|c|}{ 察 驗 前 } & \multicolumn{2}{|c|}{ 第 1 週 間 } & \multicolumn{2}{|c|}{ 第 2 週 間 } & \multicolumn{2}{|c|}{ 第 3 週 間 } & \multicolumn{2}{|c|}{ 第 4 媐 間 } \\
\hline & & 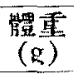 & $-\mathrm{HI}^{*}$ & 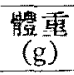 & $\mathrm{Hb}$ & 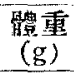 & $\mathrm{Hb}$ & 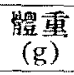 & $\mathrm{Hb}$ & $\begin{array}{c}\frac{\text { 體重 }}{(\mathrm{g})} \\
\end{array}$ & $\mathrm{HIb}$ \\
\hline 1 & \multirow{2}{*}{3} & 48 & 5.0 & 64 & 11.2 & 85 & 10.3 & 111 & 9.4 & 141 & 11.4 \\
\hline 2 & & 41 & 4.7 & 50 & 11.0 & 65 & 104 & 85 & 10.4 & 101 & 11.0 \\
\hline 3 & \multirow{2}{*}{9} & 42 & 5.2 & 51 & 12.7 & 66 & 10.9 & 78 & 13.0 & 89 & 10.7 \\
\hline 4 & & 41 & 60 & 44 & 10.8 & 51. & 12.0 & 61 & 12.9 & 71 & 12.4 \\
\hline 5 & \multirow{2}{*}{ 우 } & 43 & 60 & 50 & 11.9 & 61 & 11.5 & 72 & 9.6 & 84 & 11.7 \\
\hline 6 & & 45 & 5.9 & 48 & 11.7 & 55 & 11.9 & 60 & 11.7 & 69 & 11.8 \\
\hline 7 & \multirow{2}{*}{ q } & 57 & 5.6 & 66 & 8.6 & 78 & 11.6 & 93 & 10.9 & 110 & 11.8 \\
\hline 8 & & 63 & 6.0 & 63 & 9.7 & 68 & 13.8 & 75 & 11.8 & 85 & 13.7 \\
\hline 9 & \multirow{2}{*}{ 우 } & 53 & 6.4 & 62 & 10.4 & 65 & 11.4 & 75 & 10.1 & 92 & 11.7 \\
\hline 10 & & 57 & 3.8 & 60 & 11.0 & 58 & 12.9 & 63 & 12.5 & 72 & 12.6 \\
\hline 11 & & 65 & 5.4 & 67 & 9.1 & 69 & 10.9 & 85 & 10.2 & 90 & 12.7 \\
\hline 12 & & 59 & 5.4 & 60 & 10.9 & 57 & 13.0 & 67 & 13.1 & 73 & 15.8 \\
\hline
\end{tabular}

*血液 $100 \mathrm{cc}$ に對するへモグロビンの量 $(\mathrm{g})$ 


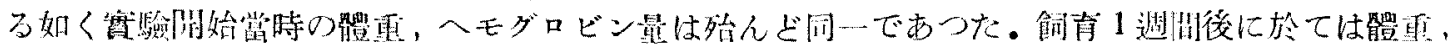

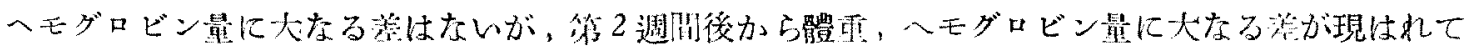

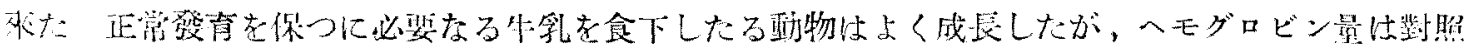

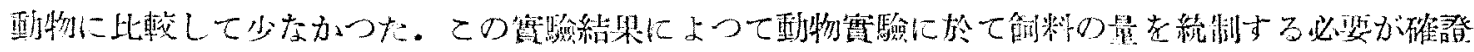
された。

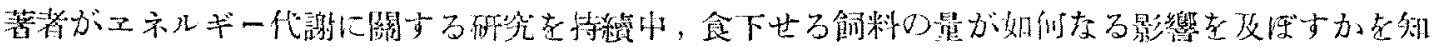

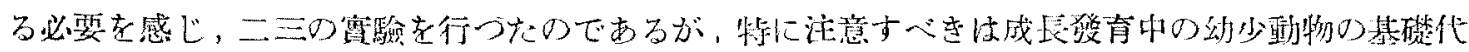

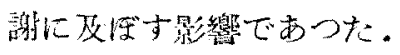

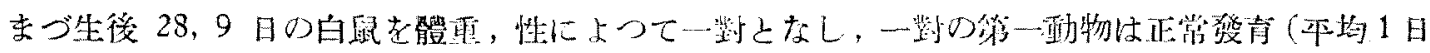

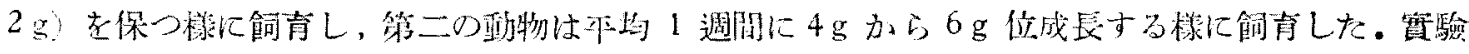

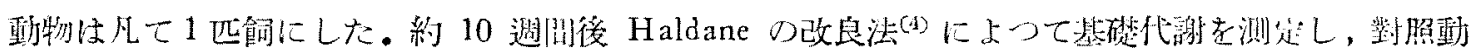

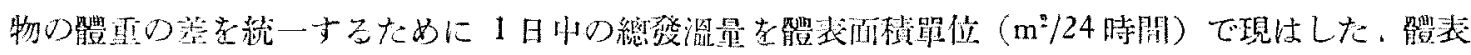

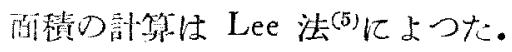

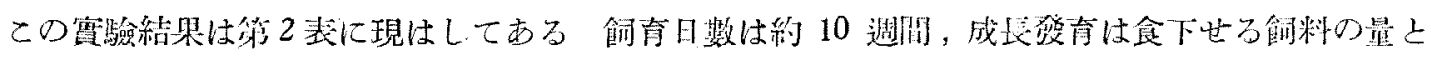

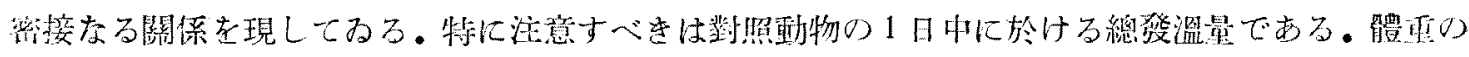

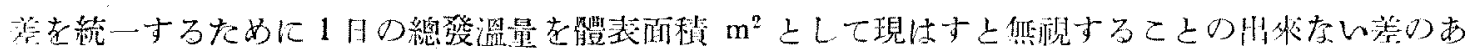

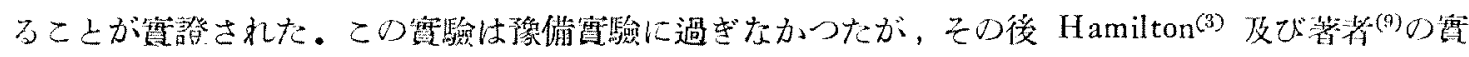

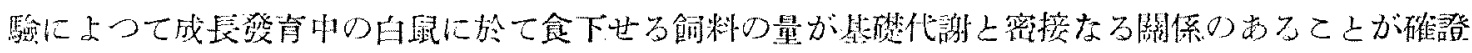
された。.

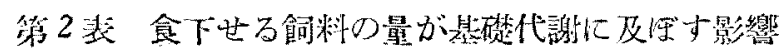

\begin{tabular}{|c|c|c|c|c|c|c|}
\hline \multirow{2}{*}{ 白鼠䅦號 } & \multirow{2}{*}{ 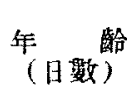 } & \multirow{2}{*}{${ }^{\text {體 }}(\mathrm{g})^{\text {重 }}$} & \multirow{2}{*}{ R. Q. } & \multirow{2}{*}{ 食下地方饲料 } & \multicolumn{2}{|c|}{ 慾溫量 (Cal.) } \\
\hline & & & & & 24 時 間 & $\mathrm{m}^{2} / 24$ 時間 \\
\hline 1 & 70 & 161 & 0.715 & 134 & 23.016 & 870 \\
\hline 2 & 70 & 82 & $0.682^{(+)}$ & 6.5 & 14.086 & 798 \\
\hline 3 & 73 & 166 & 0.727 & 13.4 & 23.352 & 867 \\
\hline 4 & 73 & 85 & 0.715 & 6.7 & 12.528 & 695 \\
\hline 5 & 71 & 140 & $0.688^{(+)}$ & 12.8 & $1^{9} .536$ & 803 \\
\hline 6 & 71 & 79 & 0.753 & 6.6 & 12.679 & 752 \\
\hline 7 & 72 & 140 & 0.741 & 11.3 & 21.792 & 900 \\
\hline 8 & 72 & 84 & 0.749 & 6.6 & 13.200 & 738 \\
\hline 9 & 74 & 153 & 0.774 & 13.1 & 21.744 & 848 \\
\hline 10 & 74 & 85 & 0.715 & 7.0 & 13.704 & 760 \\
\hline 11 & 73 & 140 & 0.700 & 11.6 & 24.096 & 991 \\
\hline 12 & 73 & 84 & 0.746 & 6.5 & 13.464 & 753 \\
\hline
\end{tabular}

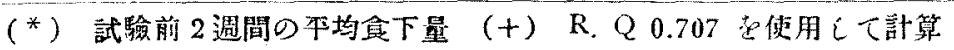

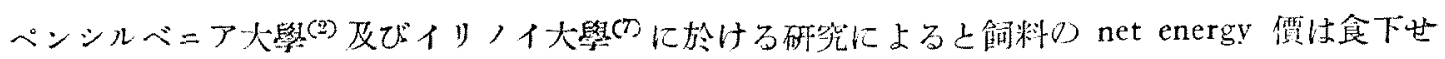

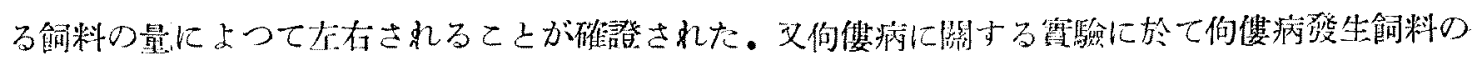




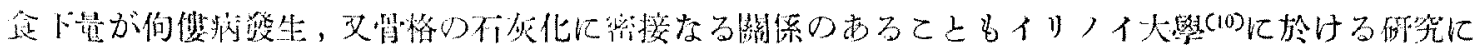

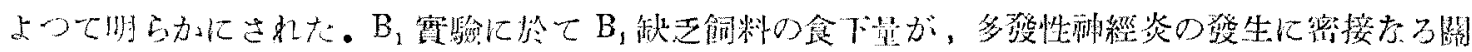

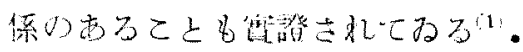

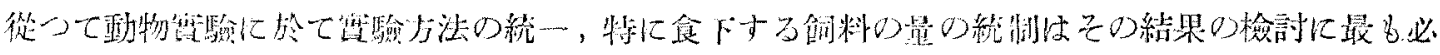

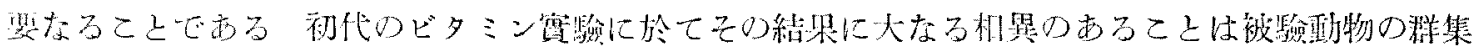

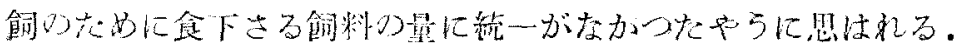

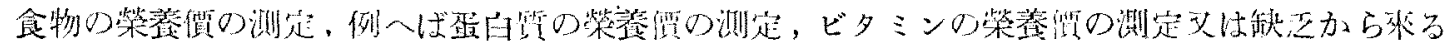

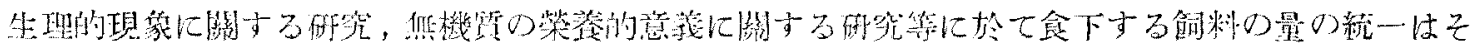

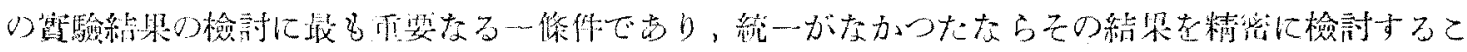
上は壮來ない上䍐はれる。

\section{文 㩆}

(1) Amantea, $G$. Sue faltore, antineurico $\left(B_{1}\right)$ e sul conceto di "quvziente beri-berico (Qb)". Rend R. Accad. Naz. Lincei, Cl. Sci. 18:317-23 (1933); Nutr. Abs, and Revs. 113: 985 (1934)

(2) Forbes, E. B. 及共同研究者: Further studies of the energy metabolism of cattle in relation to the plane of nutrition. J. Agr. Research 40:37-78 (1930)

(3) Hamilton, T. S: The lability of the basal metabolism of growing rats. J. Nutr. 17. Proc, of the 6 th Ann. Meeting of the Am. Inst. of Nutr. (1939)

(4) Haldane, J: New apparatus for measuring the respiratory exchange of animal. J. Physiol. 13: $419-30(1892)$

(5) Lee, M. O: Determination of the surface area of the white rat with its application to the expression of metabolic results. Am. J. Physiol. 89: 24-33 (1929)

(6) Mitchell, H. H., and Beadles, J. R.: The paired-feeding meth d in nutrition experiments and its application to the problem of cystine deficiencies in food protein. J. Nutr. 2: 225$43(1930)$

(7) Mitchell, H. H. 及共同研究者: The effect of the amount of feed consumed by cattle on the utilization of its energy content. I. Agr. Research 45:163-91 (1932)

(8) Nakamura, Isa,: Unpublished dala.

(9) Nakamura, Isa, Thesis: The effect of the level of phosphorus in the diet upon the metabolisn and utitization of energy, calcium, and phosphorus (1939)

(10) Watkins, W. E., and Mitchell, H. H.: The phosphurus requirements of growing chickens, with a demonstration of the value of controlled reeding. Poultry Sci. 15: 32-41 (1936) 